\title{
Last 25 years of IR thermography in Poland
}

by B. Wiecek

Institute of Electronics, Lodz University of Technology, wiecek@p.lodz.pl

The activity in the field infrared thermography in Poland has started earlier than 25 years ago. The first national conference on IR thermography was organized in 1992 and now we have started to celebrate the $25^{\text {th }}$ anniversary of the formal activity of the Polish community in IR thermography. The most important for us is the TTP Conference (Thermography and Thermometry in Infrared), originally national but today international seminar organized every 2 years. Most of them were located in Ustroń in Beskidy in the beautiful Polish mountain region. Once, in 2013, we moved to Lviv, to Lviv Polytechnic National University due to the close cooperation between the Polish and the Ukrainian Universities in the domain of IR thermography. Twice we had pleasure and honor to host QIRT Conference, in 1998 in Lodz and in 2008 in Cracow.

Dr. Piotr Pręgowski was the first organizer of TTP Conference. He was the researcher and the teacher at Military University of Technology in Warsaw. Since 1998, the organization of TTP Conferences was taken over by the Institute of Electronics in Lodz University of Technology.

During TTP Conference, the first day is the School of Thermography - courses and tutorials given by the scientists and experienced users of IR technique. The exhibition of IR systems and software is always an interesting part of our meetings. We cooperate with Measurement Automation Monitoring Journal and the most valuable papers are always publish there after the reviewing process - fig. 1.

Meantime, the daughter conference on Medical Thermology is organizing annually in Zakopane in Tatra mountains. Prof. med. Anna Jung from Military Institute of Medicine in Warsaw is the chair of this seminar. This conference is still the unique place to gather scientists and medical staff to discuss the progress in IR techniques in biomedicine.

There are at least 8 main centers dealing with IR thermography in Poland: Military University of Technology (prof. Henryk Madura), Gdansk University of Technology (prof. Antoni Nowakowski), Lodz University of Technology (prof. Bogusław Więcek), AGH University of Science and Technology in Cracow (prof. Alina Wróbel), Czestochowa University of Technology (prof. Waldemar Minkina), Military Institute of Medicine in Warsaw (prof. Anna Jung), Military Institute of Armament Technology (prof. Waldemar Swiderski) and Poznan University of Technology (Dr. Leszek Różański).

There are several books on IR thermography published recently by Polish authors: A. Nowakowski, A. Jung, J. Żuber, W. Minkina, B. Więcek, A. Wróbel, M. Fidali and S. Dudzik - fig. 2-4, [1-12]. Prof. Antoni Rogalski from Military University of Technology published a few books on infrared detectors.

In 2009 our IR community decided to create the countrywide nonprofit engineering society - the Committee of Thermography and Thermometry in Infrared (CTTP). The Committee is the part of POLSPAR - Polish Society of Measurement, Automation and Robotics, being the member of worldwide societies IFAC (The International Federation of Automatic Control), IFC (The International Federation of Robotics) and IMEKO (International Measurement Confederation). The main aim the CTTP society is to prepare and supervise the teaching courses and exams for certification the operators of IR equipment for different IR techniques: non-destructive testing, buildings, electrical and energy systems, industrial installations, medicine, etc. Presently, we have more than 50 members.
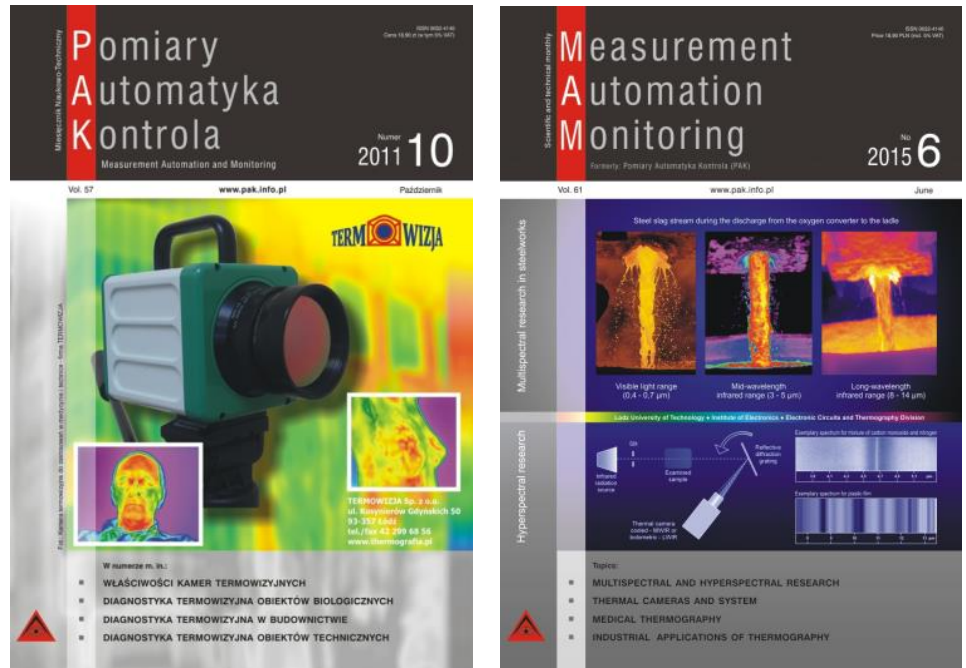

Fig. 1. Two exemplary issues of MAM journal as TTP conference proceedings 

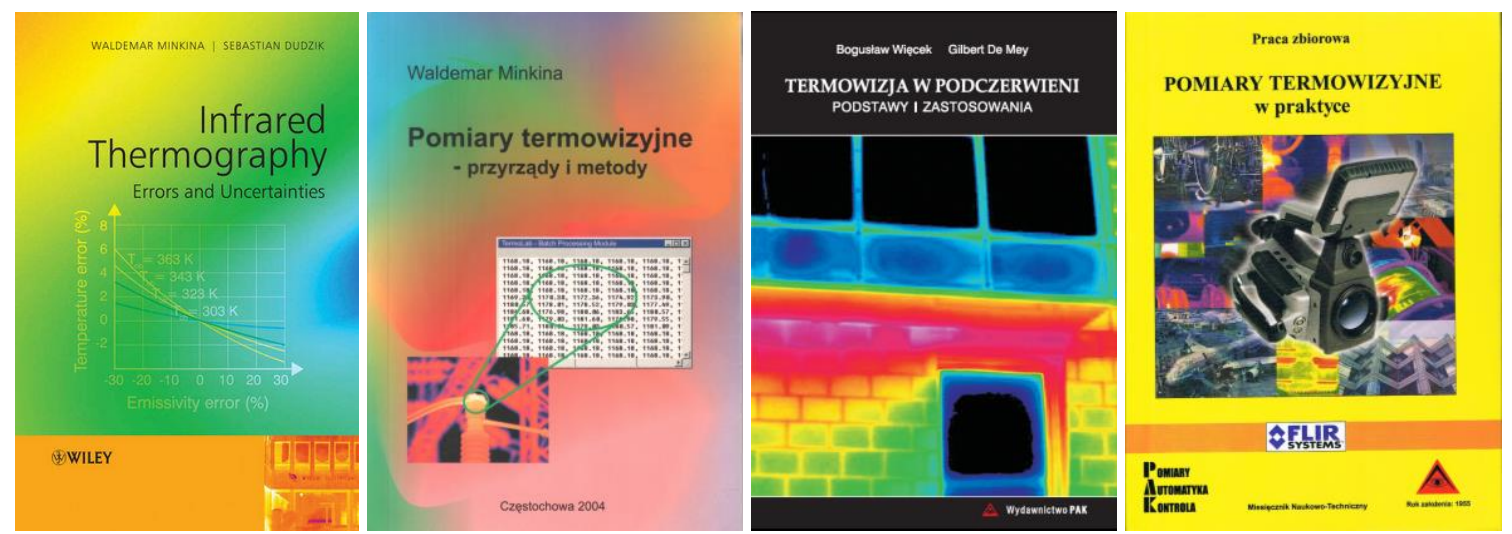

Fig. 2. The books on general thermography
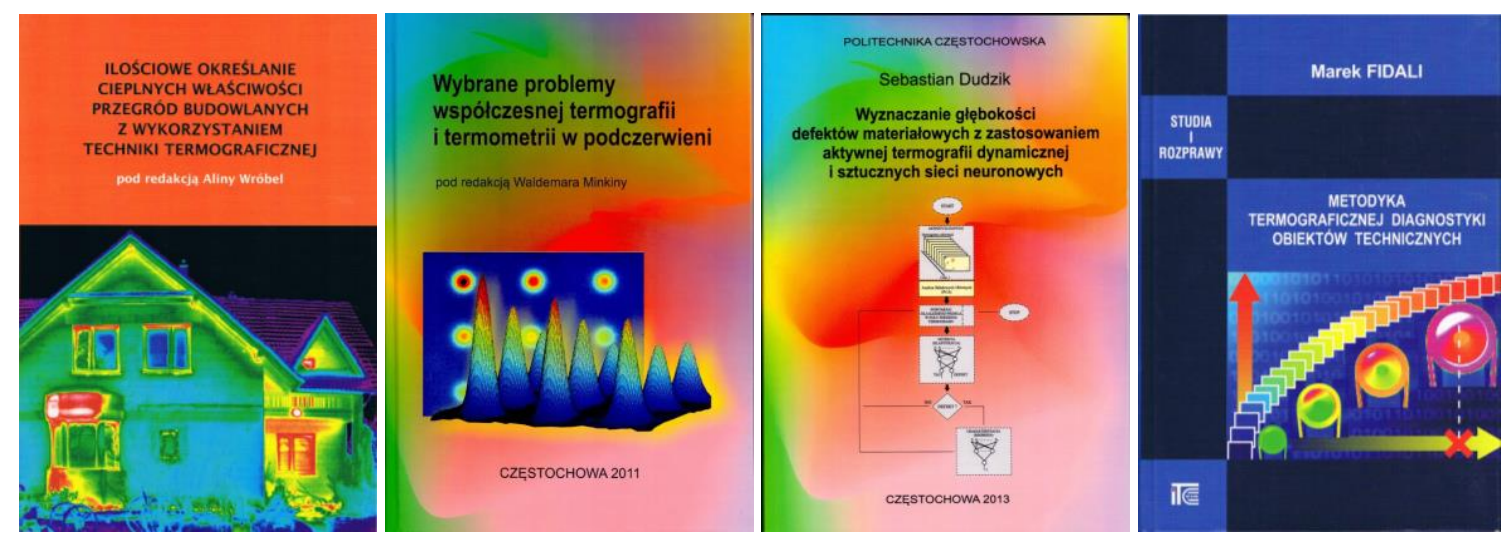

Fig. 3. The books on different applications of IR thermography: NDT, buildings, system diagnosis and maintenance
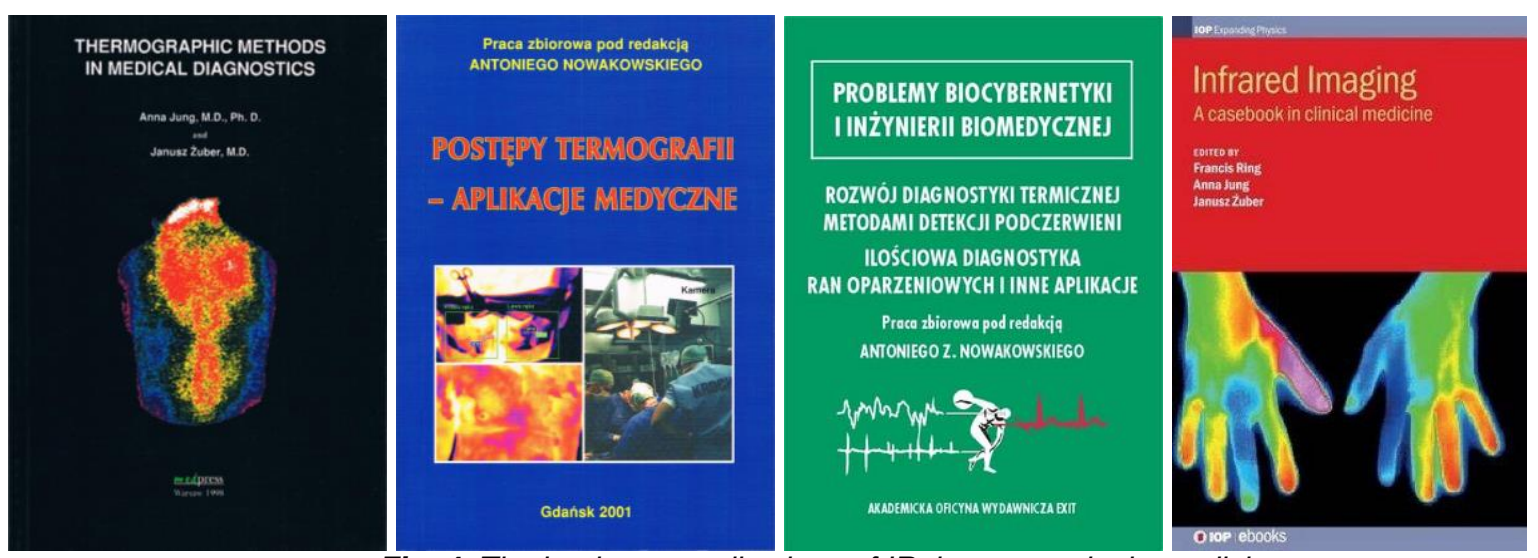

Fig. 4. The books on applications of IR thermography in medicine

There are companies and Universities that are developing IR systems and software. Not many of us remember that the first Polish IR camera (cooled scanner) was developed in the '80s last century by the group of doc. Stanisław Poloszyk and dr Leszek Różański in Poznań University of Technology - fig. 5. Recently, the first IR sight has been developed at Military Academy of Technology achieving the production status now - fig. 6 . The IR systems based on aSi and VOx technology were designed and developed, mainly for medical applications (Lodz University of Technology) fig. 7. The interesting device has been developed recently - low cost IR system having the certificate for operation in the explosive atmospheres - fig. 8. There are IR systems developed both for various military and civil applications, mainly for surveillance (Vigo Systems, Etronika) - fig. 9,10. There is an unique company producing the measurement apparatus for IR systems - InfraMet [19]. Many centers are developing their own software for thermal image processing both for medical and civil applications. 


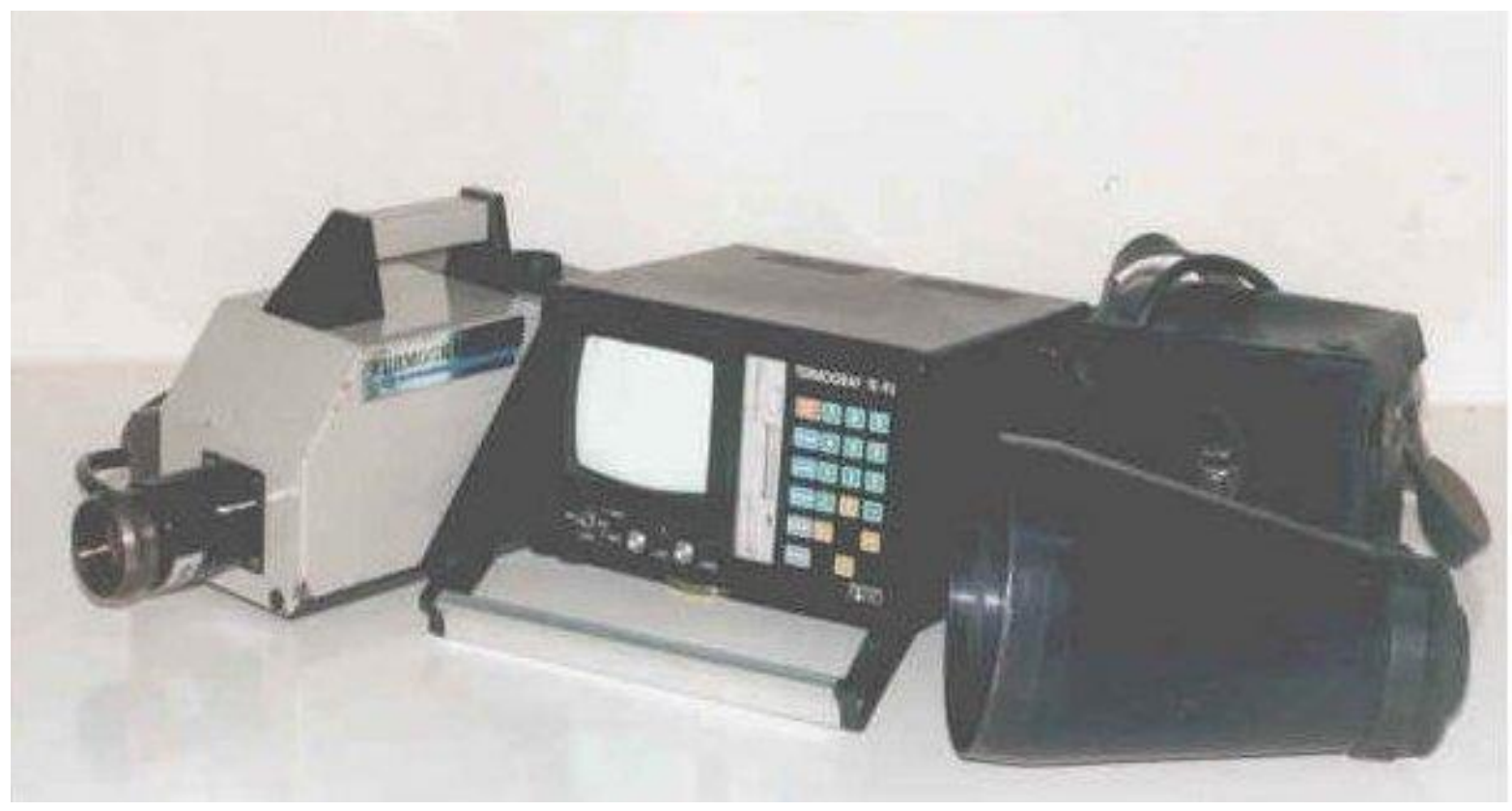

Fig. 5. The first developed in Poland IR cooled scanner, TE-93 (Poznan University of Technology), [14]

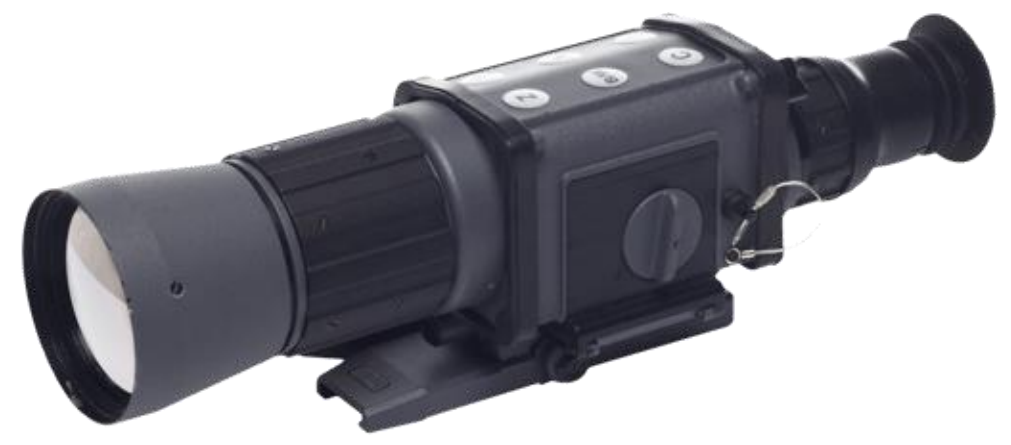

Fig. 6. The first developed in Poland IR sight (Military University of Technology in Warsaw) [15]

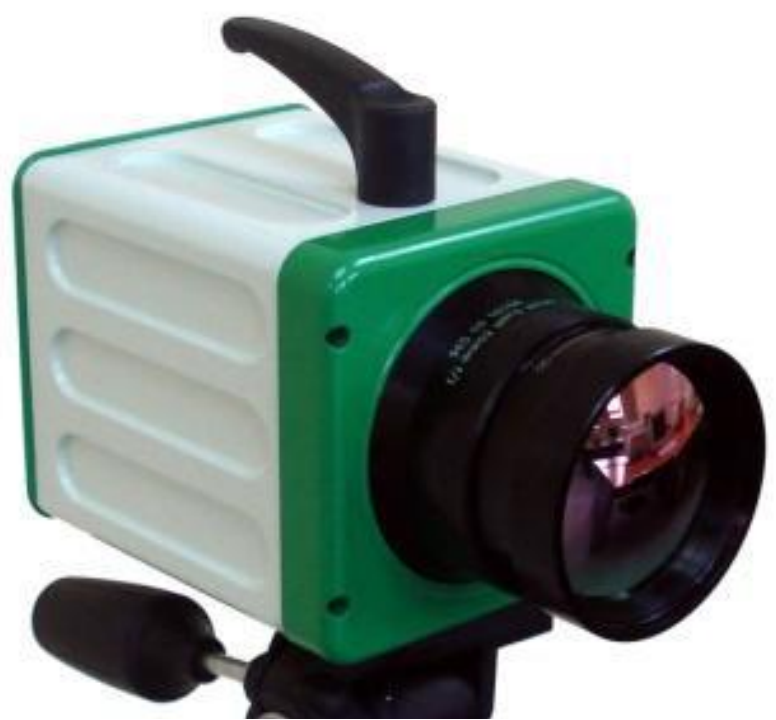

Fig. 7. The first IR camera developed in Poland high sensitive with VOx detector (Lodz University of Technology), [13] 
10.21611/qirt.2016.c

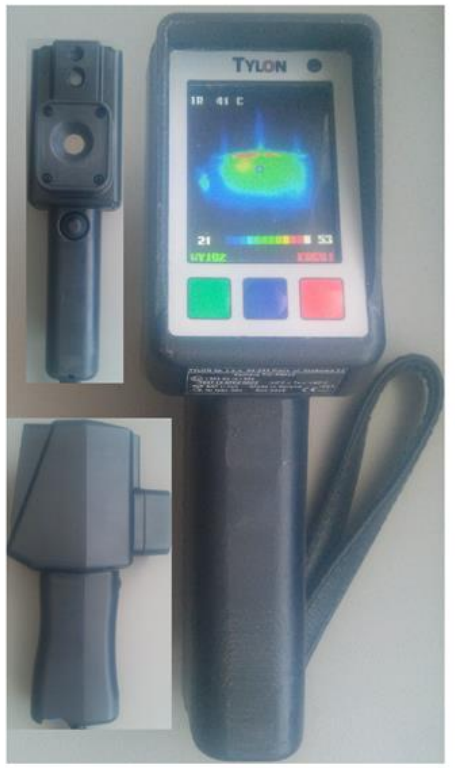

Fig. 8. The first IR camera developed in Poland TIC-PM10 with EX certificate (for explosive atmospheres) [16]
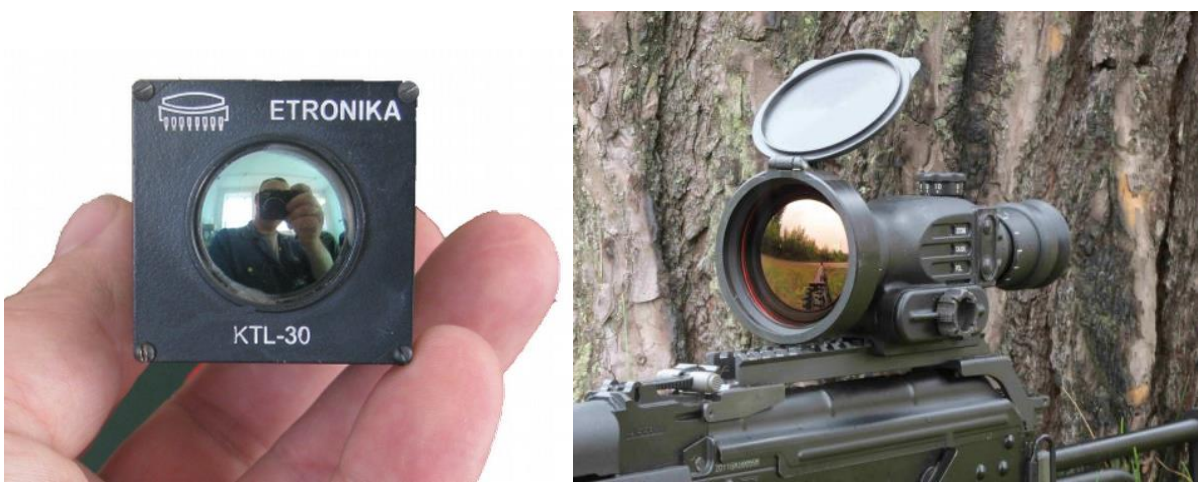

Fig. 9. Miniature bolometer camera and gun sight from Etronika company [17]
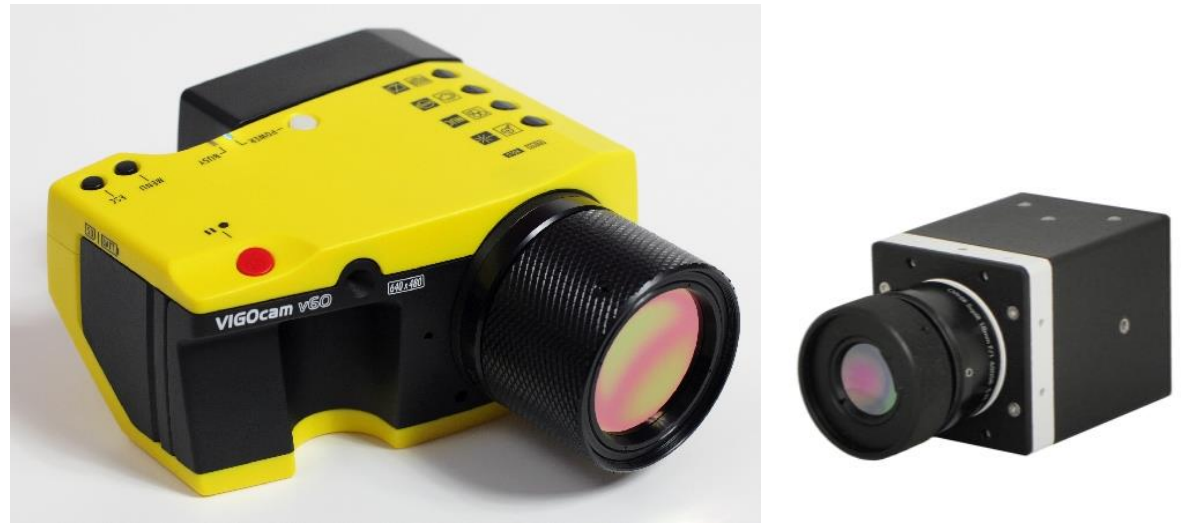

Fig. 10. Hand-held and miniature bolometer cameras from Vigo System SA [18] 


\section{REFERENCES}

[1] Minkina W., Dudzik S.: Infrared thermography - errors and uncertainties, John Wiley \& Sons Ltd, Chichester 2009 r., 192 pp, ISBN 978-0-470-74718-6, OnlineBooks ${ }^{\text {TM }}$ ISBN 978-0-470-68223-4.

[2] Minkina W. (red.): Wybrane problemy współczesnej termografii i termometrii w podczerwieni, Wydawnictwo Politechniki Częstochowskiej, Częstochowa 2011, ISBN 978-83-7193-512-1, 149 str., ISSN 0860-5017.

[3] Minkina W.: Pomiary termowizyjne - przyrządy i metody, Wydawnictwo Politechniki Częstochowskiej, Częstochowa 2004, 243 str., ISBN 83-7193-237-5.

[4] Dudzik S.: Wyznaczanie głębokości defektów materiałowych z zastosowaniem aktywnej termografii dynamicznej $i$ sztucznych sieci neuronowych, Publisher Wydawnictwo Politechniki Częstochowskiej, Częstochowa 2013, pp. 206. ISBN 978-83-7193-572-5, ISSN 0860-5017.

[5] Więcek B., De Mey G., Termowizja w podczerwieni, podstawy i zastosowania, Wydawnictwo PAK, 2011.

[6] Fidali M.: Metodyka termograficznej diagnostyki obiektów technicznych, Wydaw. Naukowe Instytutu Technologii Eksploatacji - Państwowego Instytutu Badawczego, Radom, 2013, 206s.

[7] Wróbel A. (red.): Ilościowe określanie cieplnych właściwości przegród budowlanych z wykorzystaniem techniki termograficznej, Wydawnictwa Naukowe/Akademia Górniczo-Hutnicza im. Stanisława Staszica w Krakowie, Editor:, ISBN: 978-83-7464-393-1.

[8] Madura H. (red.): Pomiary termowizyjne w praktyce, Agenda Wydawnicza PAKu, Warszawa, 2004. 176 str., ISBN 83-87982-26-1.

[9] Jung A., Żuber J.: Thermographic Methods in Medical Diagnostics, Medpress, Warszawa, 1998.

[10] Nowakowski A. (red.): Postępy termografii - aplikacje medyczne, 235 stron, Wyd. Gdańskie, 2001.

[11] A. Nowakowski (red.): Rozwój diagnostyki termicznej metodami detekcji podczerwieni (ilościowa diagnostyka ran oparzeniowych i inne aplikacje, Akademicka Oficyna wydawnicza EXIT, Warszawa, 2009.

[12] Ring F., Jung A., Żuber J.: Infrared Imaging: A Casebook in Clinical Medicine, IOP Publishing Ltd., Bristol, 2015

[13] Strąkowski R., Strąkowska M., Więcek B.: Metrological thermovision camera with VOx microbolometer, PAK vol. 57 , no. $10 / 2011$

[14] http://zmisp.mt.put.poznan.pl/index.php?section=69

[15] http://www.ioe.wat.edu.pl/

[16] http://www.status.net.pl/status/karty katalogowe/Ex/Karta\%20katalogowa\%20TIC-PM10.pdf

[17] http://www.etronika.pl/home.aspx

[18] http://www.vigo.com.pl/

[19] http://www.inframet.com/blackbodies.htm 